\title{
Transition from heathland to scrub in south-eastern Tasmania: extent of change since the 1970s, floristic depletion and management implications
}

\author{
Tessa Bargmann · Jamie B. Kirkpatrick
}

Received: 10 July 2014/Revised: 5 September 2014/ Accepted: 18 September 2014/ Published online: 30 September 2014

(C) The Author(s) 2014. This article is published with open access at Springerlink.com

\begin{abstract}
Heathland is a speciose and floriferous vegetation type, defined by its stature $(<2 \mathrm{~m})$ and dominance by scleromorphic shrubs. Heathland has been in decline globally, and much of its loss has been due to less frequent fire, while in some places more frequent fire has resulted in degradation through the loss of obligate seeding species. The aims of the present study were to determine: (1) the extent of the transition from heathland to scrub in south-eastern Tasmania, Australia between c1976 and 2013; (2) the spatial attributes of heathland that are likely to have been the most instrumental in heathland loss; (3) whether the transition to scrub resulted in the loss of local species richness and changed species composition when taking both above ground vegetation and the soil seed bank into account; and (4) the implications of the answers to the first three questions for heathland management. Changes in heathland and scrub extent were mapped from remote sensing imagery and ground truthing. At one locality with floristic data from the heathland of 1976, the scrub that has replaced the heathland was surveyed and soil collected to determine seed banks under heating and non-heating treatments. Approximately one third of the 1976 heathland had become scrub by 2013, mostly around the margins of heathland patches and near built up areas. Twenty-two species present in 1976 were not found in either the scrub or seed bank, with only three species absent from the scrub, but present in the 1976 heath, being found in the seed bank. The species composition of germinates in the unheated treatment was dominated by taxa that colonise mechanically disturbed areas, such as Juncus, while germinates in the heat treated soils were largely scleromorphic heath species. The depletion of species richness by the transition to scrub, and the large extent of its
\end{abstract}

Communicated by Stephen Garnett.

T. Bargmann $(\bowtie)$

Department of Biology, University of Bergen, Thormøhlensgate 53 A, 5006 Bergen, Norway e-mail: tessa.bargmann@bio.uib.no

J. B. Kirkpatrick

Geography and Spatial Science, School of Land and Food, University of Tasmania,

Sandy Bay Campus, Hobart 7001, Australia 
incidence, suggest that a higher frequency of planned fire is needed in south-eastern Tasmania.

Keywords Biodiversity conservation - Landscape change · Fire · Heat shock · Prescribed burning $\cdot$ Germination · Australia

\section{Introduction}

Heathlands world-wide are under threat. Land clearance has been widespread, as in the South African fynbos and Australian heathlands, where exotic plant invasion can also be a problem (Richardson et al. 1996; Kirkpatrick and Harris 1999). The cessation of traditional management practises, such as grazing and turf cutting, has eliminated many European heathlands (Gimingham 1994). Within the areas of heathland that remain, a major actual and potential threat is increased times intervals between fires, which, in some climates, can enable a replacement of heathland by taller vegetation types (Gimingham 1972; Kaland 1986; Schwilk et al. 1997).

Australian lowland heath is a diverse vegetation formation with a wide climatic range, characterized by dominance of scleromorphic shrubs and sedges less than two metres tall (Keith et al. 2002). In climates suited to forest growth, such as those in Tasmania, the formation occurs where tree species cannot grow fast enough to attain tree stature between fires because of one or more of oligotrophic soils, shallow soils, poor soil drainage and exposure to salt spray (Kirkpatrick and Harris 1999). In all areas, fire influences species richness, structural and dominance patterns. Thus, whether or not it has played a major role in the evolution of heath species, fire has a major role in maintaining heathland, and is a significant factor determining community assemblages and species distributions (Bond and Keeley 2005; Keeley et al. 2011).

Many heathland species have been shown to have adaptations that allow them to survive frequent fire (Bell 1999) and benefit from the cues for germination provided by heat and smoke (Dixon et al. 1995; Keith 1997; Gilmour et al. 2000; Kenny 2000; Van Staden et al. 2000). In fact, along with moisture, fire is likely to be the most important germination cue for many Australian heathland species (Bell 1999), with up to $40 \%$ of species being promoted in their germination by fire (Crosti et al. 2006). This is a pattern that is common in many fire-dependent plant communities, in areas such as the Mediterranean basin (Keeley 1986; Moreira et al. 2010), the South African fynbos (Lange and Boucher 1990; Brown 1993; Brown et al. 2009), and the Californian chaparral (Wicklow 1977; Keeley and Bond 1997; Keeley and Fotheringham 1997).

Despite the pervasive nature of fire in heathland ecosystems, the ideal intervals and intensities of fires are not easy to determine. Repeated frequent burns have the potential to convert heath into sedgeland (Bradstock et al. 1997). In the case of infrequent fires, heathland can become scrub; vegetation with more than $30 \%$ projective canopy cover of scleromorphic shrubs greater than $2 \mathrm{~m}$ tall. Bradstock et al. (1996) found that a heathland Banksia species best survives when the fire size is large, its frequency is intermediate, and the patches that are burnt are contiguous rather than patchy. Variability in fire frequency may also be an important factor in the maintenance of species diversity in Mediterranean ecosystems, with fire suppression being detrimental (Tucker and Cadotte 2013). There is a general agreement that the fire frequencies needed to maintain speciose heathland vary with environment and biota (i.e. Kirkpatrick and Harris 1999; Keith et al. 2002), and that 
too infrequent as well as too frequent fires are deleterious to heathland communities (Kirkpatrick and Harris 1999; Keith et al. 2002; Enright et al. 2012). In Australian heathlands, fire return times vary quite considerably, between 1 to more than 50 years. Fire intervals at either extreme are considered to be detrimental to heathland species diversity (Keith et al. 2002), as well as to cause major changes in community composition, structure and function (Enright et al. 2012). Long intervals between fires also reduce regenerative capacity, increase senescence and result in an overall population decline (Enright et al. 2012; Gosper et al. 2012).

While there is an apparent loss of plant species when heath turns into scrub, many species may be able to survive in the soil seed bank (Russell and Parsons 1978; Molnar et al. 1989). Keith et al. (2002) have shown that in some eastern heathlands three quarters of species have persistent soil seed banks. This may mean that some species lost in the above ground vegetation may be able to re-establish after fire. However, it has also been shown that the similarity between standing vegetation and seed bank can be as little as 11-38 \% (Wills and Read 2002). A later study of Australian heathland by the same authors also showed a low similarity, with $32 \%$ of species in the soil seed bank not present above ground, $63 \%$ of above ground species not recorded and $29 \%$ of species found in very low abundance in the seed bank (Wills and Read 2007). Therefore, although seed banks may be valuable in maintaining some heathland species through a period without fire, they cannot be relied on to maintain all.

Australian heathland species are known to have a wide range of life history traits related to fire that do not require a persistent soil seed bank, including vegetative resprouting and pyrogenic flowering. About $67 \%$ of Australian heathland species are known to regenerate after fire by resprouting (Pausas et al. 2004). Furthermore, the mode of regeneration is often the most important factor determining species absence in the seed bank, and species found in the above ground vegetation but not the soil seed bank are more likely to have the capacity to resprout after fire (Wills and Read 2007). However, although this trait may be useful given appropriate fire intervals, it may make it difficult for such heath species to persist once they have been lost from the above ground vegetation. To further complicate matters, species typical of Australian lowland coastal heath appear to have a limited capacity for long distance dispersal, as the majority of them have large, heavy seeds (Keith et al. 2002). This means that fire regimes are of the utmost importance in the management of Australian lowland heath.

Although too frequent burning is detrimental to heathland communities, in Tasmania, Australia, the main threat to lowland heath is a lack of fire. There is strong evidence to suggest that fire was used by the Aboriginal people of Tasmania in a way that maintained heathland near the coast (Thomas and Kirkpatrick 1996; di Folco and Kirkpatrick 2013). The same coastal areas were burned frequently by Europeans until the late twentieth century, after which prevention and control of fire in coastal regions became widespread, leading to dramatic changes in vegetation, such as the expansion of Acacia sophorae scrub on coastal sand dunes (Chladil and Kirkpatrick 1989; Hayes and Kirkpatrick 2012). Eastern Tasmanian coastal heath was floristically surveyed and mapped in the mid 1970s (Kirkpatrick 1977), before this land management change occurred. In the present study of south-eastern Tasmania, we aim to determine how the change in fire management has changed the area and species composition of Tasmanian coastal heath, and to what extent this loss is reversible. We address four questions in relation to the heathland to scrub transition: (1) how much of the heath mapped by Kirkpatrick (1977) has become scrub; (2) which spatial attributes of the heathland are likely to have been the most instrumental in heathland loss; (3) does the transition to scrub result in the loss of local species richness and change species composition when taking both above ground vegetation and the soil 
seed bank into account; and (4) what are the implications of the answers to the first three questions for heathland management?

\section{Methods}

Landscape level change

Landscape level changes were identified by comparing the aerial photographs used to produce the maps in Kirkpatrick (1977) (Tasman Peninsula: Forestry 1966 (scale 1:15,840), Derwent-D'entrecasteaux 1966 (scale 1:31,680) and Freycinet-Swansea 1978 (scale 1:17,000)) to digital images from 2010 for the areas shown on Fig. 1. To determine the amount of heathland loss, we compared total area of heath for both time periods in the different areas shown in Fig. 1 (see Fig. 2). In order to determine whether larger edges contribute to proportionate transition, we also measured the area to circumference ratio of each patch in the early aerial photographs, and compared it to the reduction in patch area. The distance from the nearest edge of each patch to the sea, and to the next patch was also measured to be able to determine whether salt spray and proximity to other heathlands, respectively, reduced the probability of heathland loss. Finally, we counted the number of patches in 2010 that were within the bounds of each single patch in the earlier time to see if patchiness of heath was associated with more loss in heathland area. All cleared areas were excluded from calculations, as we wanted to focus on heathland areas lost to a lack of fire rather than land clearance. Furthermore, the vast majority of land clearance occurred before the 1970s, so total heathland area lost to land clearance between the times periods in this study was just under $1 \%$. Maps and calculations were made in ArcMap 10. Both sets of maps were checked extensively on the ground.

\section{Vegetation and soil sampling}

Standing vegetation in 2013 was described and soils sampled in ten $10 \times 2 \mathrm{~m}$ transects at Tasman Arch (see arrow on Fig. 1) on chromosol soils on Permian mudstone on the Tasman Peninsula, Tasmania in February 2013. Transects were in a randomly chosen direction $10 \mathrm{~m}$ into an area of scrub that was mapped as heathland in the 1970s. The cover class $(<1 \%$, $1-5 \%, 5-25 \%, 25-50 \%, 50-75 \%, 75-100 \%)$ of each vascular plant species was recor$\mathrm{ded}$, and the number of individuals of each shrub/tree species taller than $50 \mathrm{~cm}$ counted. Vascular plant species occurring in scrub within $2 \mathrm{~m}$ of the long sides of the transects were also noted. Soil samples were taken with a flat trowel, at five points of equal distance from one another along each of the ten transects. The litter layer was removed before sampling. Each sample had a volume of $600 \mathrm{~cm}^{3}(10 \mathrm{~cm} \times 10 \mathrm{~cm} \times 6 \mathrm{~cm}$ depth), which was then bulked to make a $3,000 \mathrm{~cm}^{3}$ sample for each of the ten transects. The $6 \mathrm{~cm}$ depth was adopted, because at this depth, with heathland fuels, temperatures during a fire are unlikely to break dormancy (see Table 1 in Humphreys and Craig (1981)). The standing vegetation data from the 1970 s was from five $10 \times 10 \mathrm{~m}$ quadrats in the same area that we resampled in 2013. All species were recorded, but their abundance was not.

Germination experiment

All samples were passed through a $5 \mathrm{~mm}$ sieve shortly after collection, and then split into two equal parts; one for the heat treatment and one without. For the heat treatment, soil was 


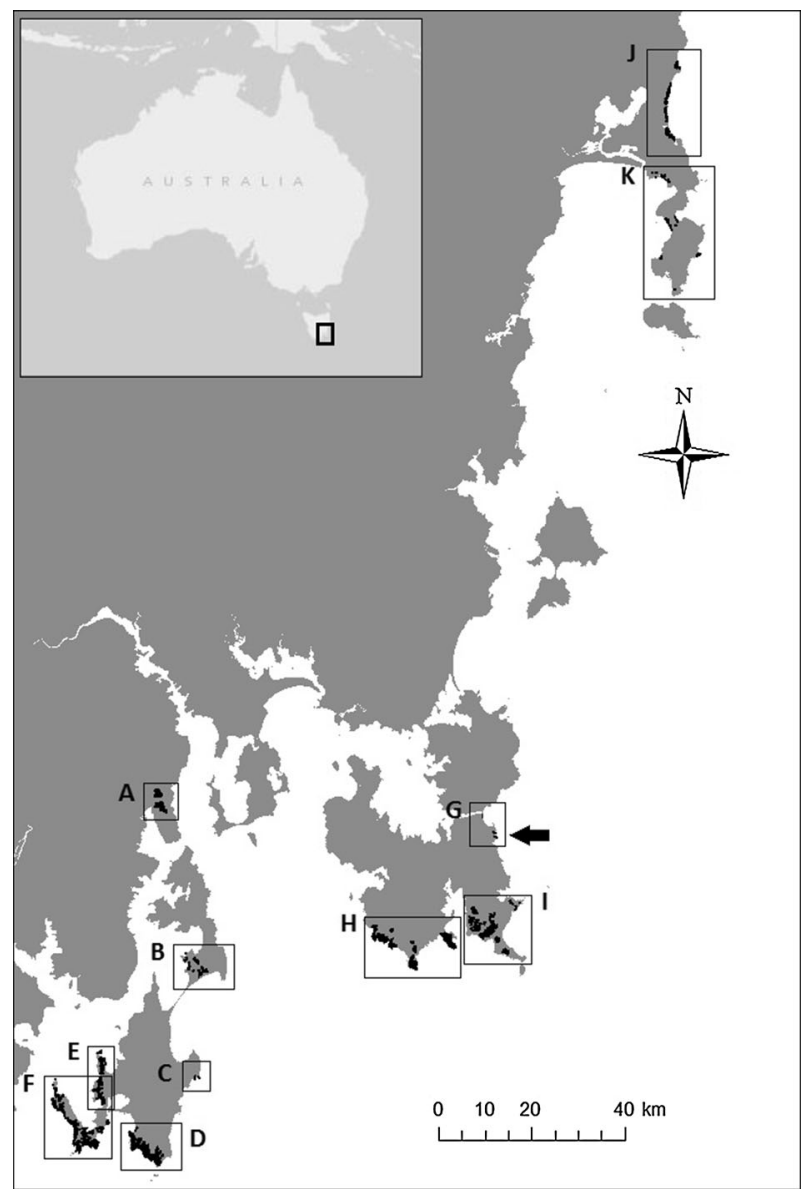

Fig. 1 South-eastern Tasmania, showing heath cover as mapped in the 1970s and the locations of the regions in Table 1. A Blackmans Bay, $B$ Bruny North Island, $C$ Cape Connella, $D$ Tasman Head, $E$ Ventiana Point, $F$ Cape Bruny, $G$ Tasmans Arch, $H$ Tasman Peninsula (East), $I$ Tasman Peninsula (West), $J$ Friendly Beaches, $K$ Freycinet. The arrow indicates where soil seed bank samples were taken at Tasman Arch

placed in an oven preheated to $100{ }^{\circ} \mathrm{C}$ for $1 \mathrm{~h}$. During treatment, the temperature in the oven did not exceed $80{ }^{\circ} \mathrm{C}$, which is the temperature that has been suggested to promote the germination of many Australian species, and which is equivalent to a medium intensity fire (Auld and O'Connell 2006). Both the heat-treated and non-heat treated samples were then potted in a $1.5 \mathrm{~cm}$ thick layer on $3 \mathrm{~cm}$ of sterile subsoil. In addition, there were four controls with only sterile soil, resulting in 24 trays. All trays were placed randomly in a non-heated greenhouse on the 20th of February, and were watered as needed. To eliminate block effects, trays were moved to a new position every 2-3 days. Seedlings began to emerge 12 days after the soil was placed in the trays. The trays were observed for 9 months to detect species that had delayed germination and to allow the individuals of some species to become identifiable. We recorded presence or absence of species by tray, rather than abundance, because abundance of individual species was contingent upon the competition that remained in the trays. 


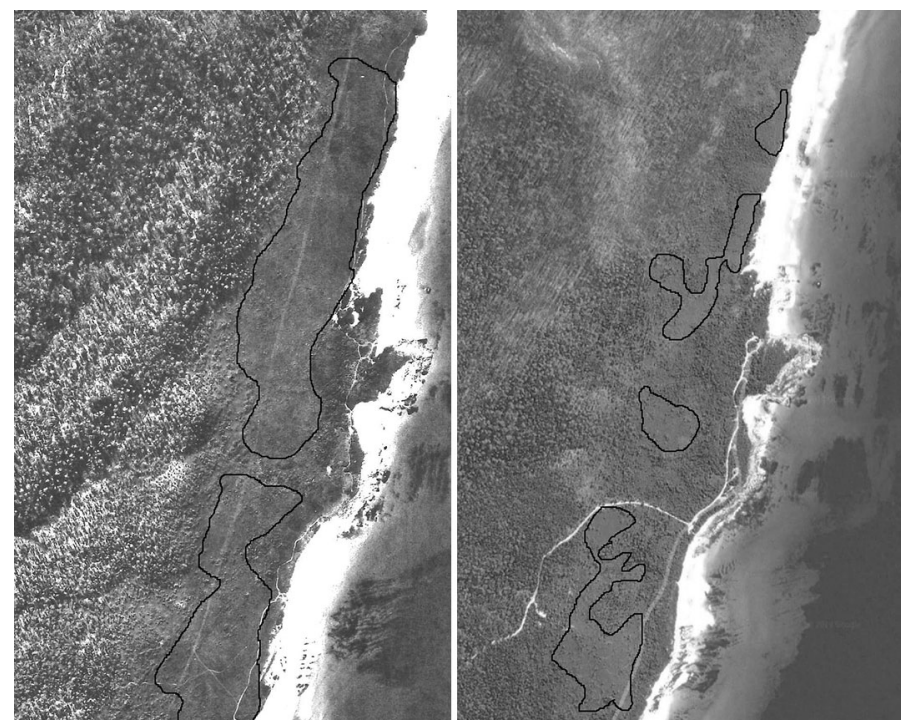

Fig. 2 Paired photographs showing heath boundaries at the two times in an area at the Friendly Beaches (left: 1978, right: 2010). Photographs courtesy of the Department of Primary Industries, Water Parks and Environment, Tasmania, and Google maps

\section{Statistics}

In order to determine which factors contributed to a reduction in heathland area from 1970s to present day, generalized linear models using a quasi-binomial distribution were used. The response variable was the proportionate loss of heathland area. Predictor variables were; original area of the patch in the 1970s, shortest distance to the nearest patch, shortest distance to the sea, the ratio of area to circumference, as well as the number of fragments that are currently in the original patch. The number of new patches per original patch ranged from 0 to 6 , which was problematic as 0 patches represent a complete loss of the original patch which is not meaningful as a value of patch number within the model. A removal of all these data entries was not deemed to be appropriate either, since these are the areas that experienced the most dramatic loss, and are likely to have been the most fragmented before disappearing completely. We therefore assigned a value of 7 to all patches that had lost all of their original area. ANOVA was used to test for the marginal effects of each of the response variables against each other in order to choose the model that best explained the data.

To get an overview of the types of species that were lost from the original heath we retrieved trait data from the TRY plant trait database (Kattge et al. 2011) on species regeneration capacity after fire (Bradstock, unpublished dataset). We also noted life form and if the species was invasive or native. Fisher's exact tests were used to determine if there were differences between species composition in the seed bank and the above ground vegetation of both years. A Sørenson similarity of species composition was also calculated for the above ground vegetation between time periods.

The species composition of germinates from the seed bank in the heated and un-heated treatment was compared using constrained analysis of principal coordinates. ANOVA was used to determine if the scores on the constrained axis (15\% of variance) differed between heated and unheated trays. Chi squared tests were used to test whether species frequencies 
were different between the two treatments. All data analysis was done in R version 2.15.3 (R Core Team 2013). Species nomenclature follows Baker and de Salas (2013).

\section{Results}

Landscape level change

There has been a substantial reduction in the extent of coastal heathland in south-eastern Tasmania, with a loss of $32 \%$ of the previous total heathland area to scrub (Table 1). The transition from heathland to scrub did not result from invasion of species from adjacent vegetation, but rather from a subset of woody heathland plants continuing to increase their height and cover until the canopy became closed at greater than $70 \%$ projective foliage cover and taller than $2 \mathrm{~m}$. These species were largely in the genera: Leptospermum, Melaleuca, Eucalyptus, Hakea, Allocasuarina and Banksia.

The smaller heathlands were most depleted (Table 1), as were those that were less remote. After testing for the marginal effects of each factor of the generalized linear model, we found that the best model included the predictor variables; number of fragments (Estimate $=0.704$, p-value $=3.47 \mathrm{e}-12$ ), the size of the heathland in 1966-1978 (Estimate $=-1.875 \mathrm{e}-7, \mathrm{p}$-value $=0.032$ ) and the distance to the nearest heathland (Estimate $=-2.074 \mathrm{E}-4, \mathrm{p}$-value $=0.050$ ), in that order (Intercept estimate $=-1.184$, d.f. $=88$ ). This suggests that fragmentation, small patch size and remoteness from the nearest patch all contribute to heathland extinction in south-eastern Tasmania.

Standing vegetation and germination experiment

A total of 54 species from 28 families were recorded in the standing vegetation in 1976, while only 33 species from 20 families were recorded from the standing vegetation in 2013 (See Appendix). The Sørenson similarity of species composition between the years was $66 \%$. Four of the species recorded in 2013 were not recorded in 1976, whereas the standing vegetation in 1976 had 24 species not found in 2013.

Table 1 Total area of heathland in hectares (ha) in 1966-1978, 2010 and the percentage lost to scrub by region (see Fig. 1)

\begin{tabular}{llrrc}
\hline Region & Site name & Area $1966-78$ (ha) & Area 2010 (ha) & $\%$ loss \\
\hline A & Blackmans Bay & 436 & 24 & 94 \\
B & Bruny North Island & 280 & 101 & 64 \\
C & Bruny Island Cape Connella & 23 & 4 & 84 \\
D & Bruny Island Tasman Head & 1,367 & 982 & 28 \\
E & Bruny Island Ventiana Point & 693 & 266 & 62 \\
F & Bruny Island Cape Bruny & 1,817 & 1,434 & 21 \\
G & Tasmans Arch & 29 & 2 & 94 \\
H & Tasman Peninsula East & 1,280 & 1,138 & 11 \\
I & Tasman Peninsula West & 1,404 & 1,190 & 15 \\
J & Friendly Beaches & 563 & 248 & 56 \\
K & Freycinet & 226 & 123 & 46 \\
& Total & 8,118 & 5,512 & $\mathbf{3 2}$ \\
\hline
\end{tabular}


Thirty-nine species from 23 families were recorded in the seed bank, of which 34 were identified to species, three were identified to family and two were identified as herbs. However, at least 18 of the 39 species were recorded neither in the 1976 nor the 2013 standing vegetation, with six of these being identified as exotic to Tasmania and all, except two shrubs, being herbs or monocots. Only three species that were not found in the standing vegetation of 2013, but were recorded in 1976, were found in the soil seed bank samples; Mitrasacme pilosa, Pimelea linifolia and Xanthosia tasmanica. The Sørenson similarity of species composition between the 2013 standing vegetation and the seed bank is 38, and $31 \%$ for the 1976 standing vegetation and the seed bank. There was very little contamination in the germination trial. Only three taxa germinated in the controls. One of these was the exotic Trifolium repens, which was recorded in two soil trays in the heat treatment. Another was a Boronia, a native taxon common in most treated trays. The third was an unidentified species of Asteraceae.

Overall, resprouters were more common than seeders $(n=32$ and 17 , respectively). Trees and shrubs were the most common life form $(n=32)$, followed by herbs $(n=19)$, graminoids $(\mathrm{n}=18)$ and ferns and lycopods $(\mathrm{n}=7)$ (See Fig. 3). Fisher's exact tests showed that species lost from the above ground vegetation in the 1970s were not significantly more likely to belong to any particular life form or regeneration category than species preserved above ground and/or in the seed bank, although herbs tended to be better preserved than graminoids ( $\mathrm{p}$-value $=0.057$ ). Specifically, of the species recorded above ground in the 1970s, herbs were more likely to be present in the seed bank in 2013 than graminoids and ferns ( $\mathrm{p}$-value $=0.028$ ). Species found in the seed bank also differed from species found only above ground in the 1970s; resprouters ( $\mathrm{p}$-value $=0.005)$ and ferns ( $\mathrm{p}$ value $=0.012)$ were both less likely to be found, while invasive species ( $\mathrm{p}$-value $=0.011)$ and herbs (p-value $=0.001$ ) were more likely to be found in the seed bank than only in the above ground vegetation. Excluding invasives, the same pattern was true for species found only above ground in 2013 versus the seed bank, where resprouters ( $\mathrm{p}$ value $=0.033$ ) and

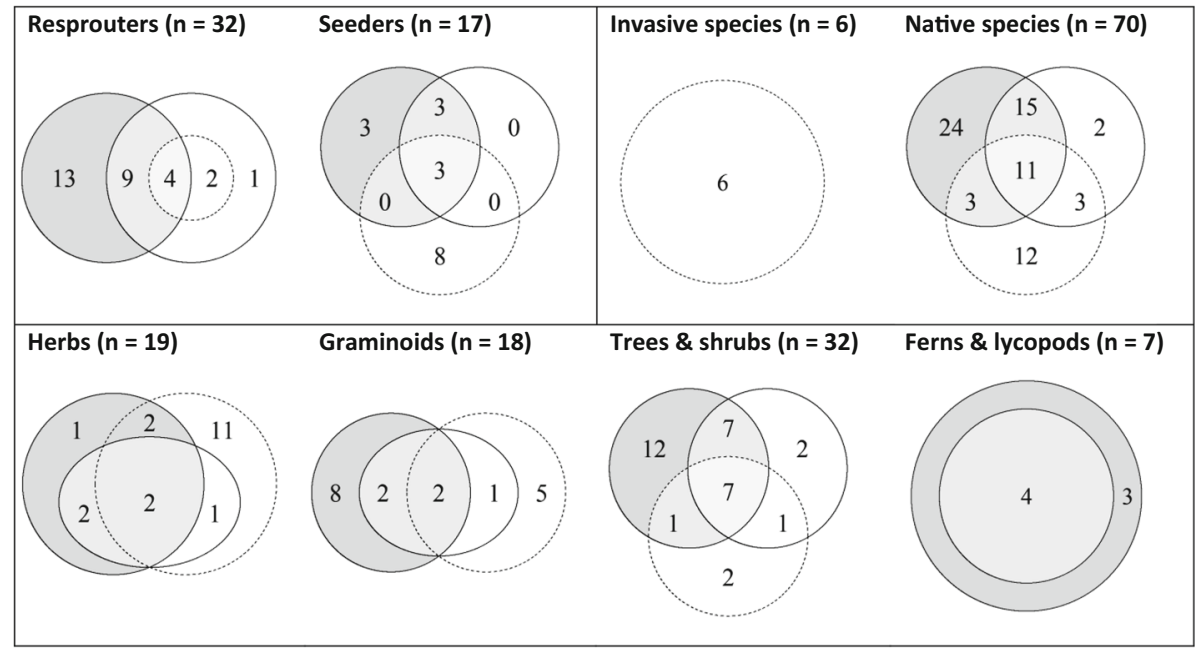

Fig. 3 Venn diagrams showing the number of species per regeneration type (resprouters and seeders), status (invasives and natives), as well as life form (herbs, graminoids, trees and shrubs and ferns and lycopods), in the standing vegetation in 1976 (gray circle), 2013 (white circle, solid line) and in the seed bank (white circle, dotted line) 
ferns ( $\mathrm{p}$ value $=0.008$ ) were less likely to be found in the seed bank, and herbs were more likely to be found than both trees $(\mathrm{p}$-value $=0.037)$ and ferns $(\mathrm{p}$-value $=0.002)$.

There was a difference (ANOVA, $\mathrm{F}_{1,18}=3.22$, p-value $\left.=0.005\right)$ in species composition between the heat treated and the non-heat treated samples. Although no individual species were significantly different in their frequency between treatments, at the generic level Juncus spp. were concentrated in the unheated treatment $\left(\mathrm{Chi}^{2}=9.8\right.$, d.f. $=1$, $\mathrm{P}=0.002$ ), and species from the Mimosaceae and Fabaceae families, all of which have hard-coated seeds, were concentrated in the heat treatment $\left(\mathrm{Chi}^{2}=7.1\right.$, d.f. $=1$, $\mathrm{P}=0.008$ ). The trees and shrubs germinated more frequently in the heat treated samples $\left(\mathrm{Chi}^{2}=5.2\right.$, d.f. $=1$, p-value 0.022$)$, while the herbs did not respond significantly in their germination to either treatment. Furthermore, while graminoids did not respond significantly to either treatment, those that are invasive and absent in the above ground vegetation (Juncus spp., Poa annua and Isolepis levynsiana) germinated more readily in the nonheated samples $\left(\mathrm{Chi}^{2}=9\right.$, d.f. $=1$, p-value 0.003$)$, while graminoids found in the above ground vegetation (Schoenus lepidosperma, Gahnia grandis and Calorophus elongatus) were more concentrated in the heat treatment $\left(\mathrm{Chi}^{2}=4.18\right.$, d.f. $=1$, p-value 0.041). Species capable of resprouting germinated significantly more in response to heat treatment $\left(\mathrm{Chi}^{2}=3.85\right.$, d.f. $=1$, p-value $\left.=0.05\right)$, while species that tend to regenerate from seed did not respond differently between treatments. Species present in the seed bank but not in the above ground vegetation of 2013 did not respond significantly to either treatment.

\section{Discussion}

Our results have shown a loss of nearly a third of heathlands mapped in 1976 to the later successional stage of scrub. There are many different types of scrub recognised in the statewide 1:25,000 vegetation mapping program, some of which are regarded to have conservation significance (Harris and Kitchener 2005). The transition from heathland to scrub we document is not one that will lead to a net improvement in the conservation status of Tasmania's biodiversity, as the transitions are not into the rarer scrub communities and involve relaxation of species numbers, as exemplified by our data.

Smaller, more fragmented and more isolated heaths lost the highest proportions of their areas to scrub. The loss has largely proceeded from the margins of heathland patches, where conditions for shrub growth may be more favourable than in the centre of patches. However, small patches on favourable sites within larger stretches of heathland have also made the transition. Heathlands close to urban areas have been particularly susceptible to loss. This is likely to be because of changes in fire regimes consequent upon urbanisation, rather than from nutrient drift, as Loofs-Samorzewski (2003) has shown a lack of effect of a realistic level of nutrient drift upon heathlands in Tasmania.

The transition to scrub is a process of increasing dominance of the potentially tallest species and the loss of species of low potential stature and shade tolerance under a closed canopy (see Fig. 4), causing an overall reduction in species richness. This transition is apparent in the scrub at Tasman Arch; in addition to an extensive loss in total heathland area, there was a reduction in species richness and similarity in the above ground vegetation from 1976 to 2013. Although species lost in the above ground vegetation did not belong preferentially to any particular life form or regeneration type, the species composition did differ in terms of its overall stature. Many common Tasmanian heath species, including the endemics Eucalyptus tenuiramis and Lomatia tinctoria, and the rare Lepidosperma tortuosum, have disappeared from the species list, and all the species observed in 


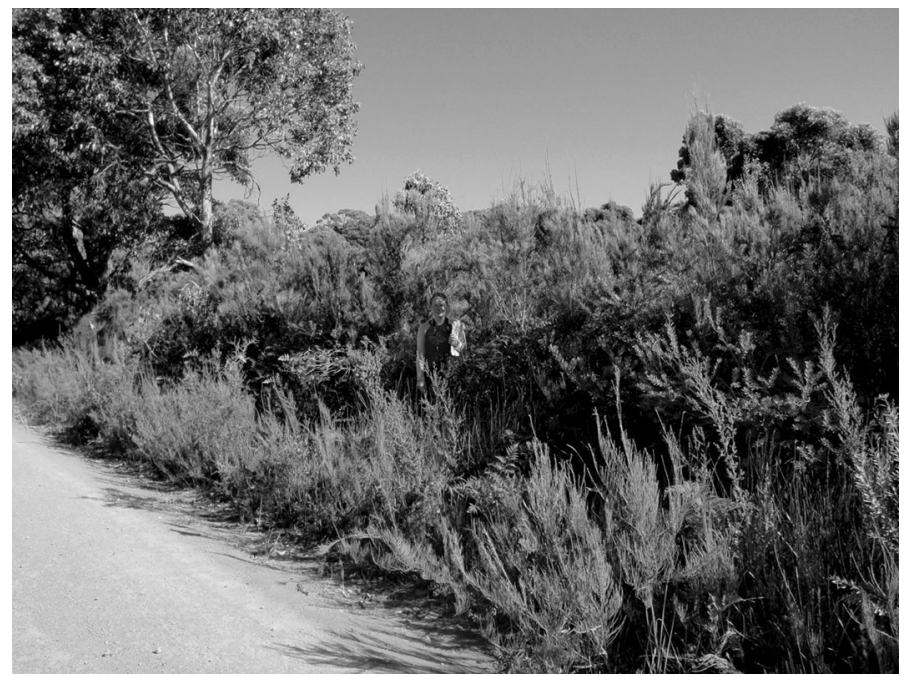

Fig. 4 Three metre tall closed-scrub dominated by Allocasuarina monilifera in a place formerly occupied by heathland on Bruny Island Tasmania, 2013

heath in 1976, but not in scrub in 2013, are small shrubs or non-woody species confined to the ground layer (See Appendix).

In addition to a reduction in above ground species richness, our soil seed experiment indicates that there may be only a weak capacity for fire to restore species composition in heaths that have become scrub. Only one eighth of the species that were observed in heath at Tasman Arch in the mid 1970s, but not in scrub in 2013, germinated from the soil seed bank. Importantly, none of the endemic or rare species lost in the above ground vegetation were found in the seed bank, and all of the invasive species recorded were found exclusively in the seed bank. This means that not only is the seed bank a poor refuge for heathland species, but it also appears to favour invasives.

The low similarity between the species composition of seed bank and above ground vegetation has been observed in other Australian heathlands (see Wills and Read 2007), and other vegetation types (Leck et al. 1989; Davies et al. 2013). A possible explanation for the low levels of similarity may be that long-lived seeds are bioturbated down the soil profile over many decades, and become isolated from the effects of fire unless fire is preceded by erosion. This process may have occurred at Tasman Arch, where the last fire that burned our transects was probably in the 1950s and there was definitely no fire after 1976. Furthermore, birds and wind may disperse species not present in the original heathland into scrub or the soil seed bank under the scrub. For example, Astroloma humifusum, a shrub species known to have a long-lived seed bank (Bezemer et al. 2013) and an attractive fleshy fruit was occasional in the seed bank but not observed in either 1976 or 2013. Leucopogon parviflorus, a bird-dispersed, but fire-sensitive, shrub (Hazard and Parsons 1977) was found in the scrub in 2013, but not heathland in 1976. Ozothamnus ferrugineus, present only in the soil seed bank, is a wind-dispersed shrub of disturbed ground. However, Wills and Read (2007) suggest that the majority of species not recorded in the seed bank may be serotinous or regenerate by resprouting, and that the capacity of the soil seed bank to change vegetation composition after fire is relatively limited. In accordance with this finding, our study also shows that resprouters are less frequently 
present in the seed bank than the above ground vegetation at both time periods. This raises the question of what will happen to obligate resprouters that are no longer present in the above ground vegetation in the long term. If dissimilarities between the seed bank and the above ground vegetation are comparable in other heathlands, which literature suggests is the case, it is especially important to prevent heath from becoming scrub.

The results from our heat treatments further support that fire is an important disturbance factor in heathland communities, and that heathland species in particular have the capacity to survive and germinate following fire (Gill 1981; Bell et al. 1984). For example, of the species that occurred more frequently in the heat treatment, two were not present in the above ground vegetation in 2013, but were recorded in 1976, and five species (Acacia genistifolia, Astroloma humifusum, Boronia parviflora/pilosa, Dillwynia glaberrima and Pimelea linifolia) are commonly found in Tasmanian heathlands (Kirkpatrick and Harris 1999). All these genera, excluding Boronia, include obligate seeders (Wills and Read 2007). In addition, graminoids that were present only in the seed bank were more common in nonheat treated samples, and those that were present in the above ground vegetation were more frequent in the heat treatment. These results strongly indicate that the vegetation resulting from mechanical disturbance of the scrub would be very different from that resulting from fire, with a predominance of Juncus species, exotic herbs and Ozothamnus ferrugineus likely after mechanical disturbance, and scleromorphic shrubs more prominent after fire.

The broad range of recommended period between fires for heathland in Tasmania (e.g. 3-50 years (Pyrke and Marsden-Smedley 2005)) reflects enormous variation in shrub growth rates and maturation times on sites occupied by heath (Enright et al. 2012). Some heaths on nutrient-poor shallow soils with high exposure to salt spray, such as those on the peak of Dover Island in Bass Strait, may need no fire to persist (Kirkpatrick 1995), while other heathlands clearly do. It is unwise to burn most Australian heaths at an interval of less than 8-10 years because of the potential loss of obligate seed regenerators (Bradstock and Myerscough 1981; Bradstock et al. 1997; Gill and Stephens 2009), however, our results strongly suggest that too frequent fire is currently not a problem, and that more frequent planned burning should be undertaken in the coastal heathlands of south-eastern Tasmania. Furthermore, since different populations of the same species can vary in their capacity to resprout or regenerate from seed after fire, it may be more useful to consider the fire response at a population level, rather than considering species response traits individually (Vivian et al. 2010). Burning should take place before heath turns into scrub, as burning after this transition may fail to regenerate a substantial subset of native species, and merely reinforce the dominance of the species constituting the scrub. This is particularly important with respect to serotinous species, whose seed banks are frequently depleted within a year of parent plant death (Enright et al. 2012). Nevertheless, more frequent burning of areas that are now scrub might eventually lead to a restoration of heathland species richness, where heathland survives as an adjacent seed source. High intensity fires are likely to result in more heath seedlings than low intensity fires, as the heat produces a greater range of temperatures in the soil.

We conclude that Tasmanian heathland managers need to increase fire frequencies and monitor the extent of Tasmanian heathlands, as well as the above ground species composition, in order to prevent further encroachment of scrub and biodiversity loss. As seed banks do not appear to be a good source of regeneration for typical heathland species, it is important that management measures are taken before heaths become too depauperate in species. Furthermore, since isolated, small and fragmented heathlands appear to be the most threatened by shrub encroachment, these heathlands should be given special attention if they are to be maintained. Large and contiguous heaths should be managed to prevent fragmentation. Managers should aim to create a heathland mosaic in which burning of 
patches occurs at variable intensity levels (Gill 1999), and historical fire regimes should be studied in order to develop the most appropriate fire intervals (Tucker and Cadotte 2013).

Acknowledgments We would like to thank the Institute of Marine Research in Bergen, the University of Tasmania and the University of Bergen for support, and the Department of Primary Industries, Parks, Water and Environment, Tasmania for permission to take soil samples. Thank you to John-Arvid Grytnes, Inger E. Måren and Vigdis Vandvik for discussions on the manuscript, and two anonymous reviewers for their helpful comments. Thanks also go to David Green for his help with field and greenhouse equipment. The study has been supported by the TRY initiative on plant traits (http://www.try-db.org). The TRY initiative and database is hosted, developed and maintained by J. Kattge and G. Bönisch (Max Planck Institute for Biogeochemistry, Jena, Germany). TRY is currently supported by DIVERSITAS/Future Earth and the German Centre for Integrative Biodiversity Research (iDiv) Halle-Jena-Leipzig.

Open Access This article is distributed under the terms of the Creative Commons Attribution License which permits any use, distribution, and reproduction in any medium, provided the original author(s) and the source are credited.

\section{Appendix}

See Table 2

Table 2 Species lists from quadrats in 1976, transects and adjacent areas in 2013 and soil seed banks (SB; "h" = heat treatment, "n" = no heat treatment) from the Tasman Arch; "n" = native, "i" = invasive, " $x "=$ presence of the species, numbers in the two "SB" columns represent the number of trays in which the given species was present and numbers in brackets represent the number of trays in which the given genus was present. The latter column shows the regeneration type after $100 \%$ scorch from various studies in the TRY database (http://www.trydb.org) where "R" = resprouter, "S" = seeder, "Rs" = usually resprouts but is sometimes killed and "Sr" = usually killed but sometimes resprouts. Nomenclature follows Baker and de Salas (2013)

\begin{tabular}{|c|c|c|c|c|c|c|c|}
\hline Species & Family & Status & 1976 & 2013 & $\mathrm{SB}(\mathrm{h})$ & $\mathrm{SB}(\mathrm{n})$ & $\begin{array}{l}\text { Fire } \\
\text { tolerance }\end{array}$ \\
\hline Acacia genistifolia & Mimosaceae & $\mathrm{n}$ & $\times$ & $\times$ & 2 & 0 & $\mathrm{~S}$ \\
\hline Acacia myrtifolia & Mimosaceae & $\mathrm{n}$ & $\times$ & & & & $\mathrm{Sr}$ \\
\hline Acacia verticillata & Mimosaceae & $\mathrm{n}$ & $x$ & $\times$ & & & $\mathrm{R} / \mathrm{S}$ \\
\hline Acaena novae-zelandiae & Rosaceae & $\mathrm{n}$ & & & 1 & 0 & $\mathrm{~S} / \mathrm{R}$ \\
\hline Allocasuarina monilifera & Casuarinaceae & $\mathrm{n}$ & $x$ & $x$ & 0 & 1 & \\
\hline Amperea xiphoclada & Euphorbiaceae & $\mathrm{n}$ & $x$ & & & & $\mathrm{R}$ \\
\hline Astroloma humifusum & Epacridaceae & $\mathrm{n}$ & & & 3 & 1 & $\mathrm{R}$ \\
\hline Banksia marginata & Proteaceae & $\mathrm{n}$ & $x$ & $\times$ & 1 & 0 & $\mathrm{R} / \mathrm{S}$ \\
\hline Bauera rubioides & Cunoniaceae & $\mathrm{n}$ & $x$ & $\times$ & 0 & 1 & Rs \\
\hline Baumea acuta & Cyperaceae & $\mathrm{n}$ & $x$ & & & & $\mathrm{R}$ \\
\hline Boronia parviflora & Rutaceae & $\mathrm{n}$ & $x$ & $x$ & -9 & -6 & Rs \\
\hline Boronia pilosa & Rutaceae & $\mathrm{n}$ & $\times$ & $\times$ & -9 & -6 & $\mathrm{R}$ \\
\hline Calorophus elongatus & Restionaceae & $\mathrm{n}$ & & $x$ & 7 & 2 & \\
\hline Calytrix tetragona & Myrtaceae & $\mathrm{n}$ & & $x$ & & & $\mathrm{R} / \mathrm{S}$ \\
\hline Cassytha glabella & Lauraceae & $\mathrm{n}$ & $\times$ & $x$ & 1 & 0 & $\mathrm{~S}$ \\
\hline Cassytha pubescens & Lauraceae & $\mathrm{n}$ & $\times$ & $\times$ & & & $\mathrm{S}$ \\
\hline Dillwynia glaberrima & Fabaceae & $\mathrm{n}$ & $x$ & $\times$ & 5 & 1 & $\mathrm{R} / \mathrm{S}$ \\
\hline
\end{tabular}


Table 2 continued

\begin{tabular}{|c|c|c|c|c|c|c|c|}
\hline Species & Family & Status & 1976 & 2013 & $\mathrm{SB}(\mathrm{h})$ & $\mathrm{SB}(\mathrm{n})$ & $\begin{array}{l}\text { Fire } \\
\text { tolerance }\end{array}$ \\
\hline Drosera sp. & Droseraceae & $\mathrm{n}$ & $x$ & $x$ & & & \\
\hline Empodisma minus & Restionaceae & $\mathrm{n}$ & $x$ & & & & $\mathrm{R}$ \\
\hline Epacris impressa & Epacridaceae & $\mathrm{n}$ & $x$ & $x$ & & & $\mathrm{R} / \mathrm{S}$ \\
\hline Epacris lanuginosa & Epacridaceae & $\mathrm{n}$ & $x$ & $x$ & & & $\mathrm{R}$ \\
\hline Eucalyptus obliqua & Myrtaceae & $\mathrm{n}$ & $x$ & $x$ & & & $\mathrm{R}$ \\
\hline Eucalyptus tenuiramis & Myrtaceae & $\mathrm{n}$ & $x$ & $x$ & & & \\
\hline Eurychorda complanata & Restionaceae & $\mathrm{n}$ & $x$ & $x$ & & & Rs \\
\hline Euryomyrtus ramosissima & Myrtaceae & $\mathrm{n}$ & $x$ & & & & $\mathrm{R} / \mathrm{S}$ \\
\hline Exocarpos strictus & Santalaceae & $\mathrm{n}$ & $x$ & & & & $\mathrm{R}$ \\
\hline Gahnia grandis & Cyperaceae & $\mathrm{n}$ & $x$ & $x$ & 3 & 1 & $\mathrm{R}$ \\
\hline Gamochaeta purpurea & Asteraceae & $\mathrm{i}$ & & & 0 & 1 & \\
\hline Gleichenia dicarpa & Gleicheniaceae & $\mathrm{n}$ & $x$ & $x$ & & & $\mathrm{R}$ \\
\hline Gonocarpus micranthus & Haloragaceae & $\mathrm{n}$ & & & 0 & 1 & S \\
\hline Gonocarpus teucrioides/humilis & Haloragaceae & $\mathrm{n}$ & $x$ & $x$ & 10 & 10 & $\mathrm{Sr}$ \\
\hline Hakea teretifolia & Proteaceae & $\mathrm{n}$ & $x$ & $x$ & & & S \\
\hline Hibbertia riparia & Dilleniaceae & $\mathrm{n}$ & $x$ & $x$ & & & $\mathrm{R}$ \\
\hline Hydrocotyle hirta & Apiaceae & $\mathrm{n}$ & & & 0 & 1 & Rs \\
\hline Isolepis levynsiana & Cyperaceae & $\mathrm{i}$ & & & 1 & 1 & \\
\hline Juncus bufonius & Juncaceae & $\mathrm{n}$ & & & 0 & 4 & $\mathrm{~S}$ \\
\hline Juncus planifolius & Juncaceae & $\mathrm{n}$ & & & 0 & 2 & $\mathrm{R}$ \\
\hline Juncus procerus & Juncaceae & $\mathrm{n}$ & & & 1 & 6 & \\
\hline Laxmannia orientalis & Liliaceae & $\mathrm{n}$ & & & 0 & 1 & S \\
\hline Lepidosperma concavum & Cyperaceae & $\mathrm{n}$ & $x$ & & & & $\mathrm{R}$ \\
\hline Lepidosperma filiforme & Cyperaceae & $\mathrm{n}$ & $x$ & & & & Rs \\
\hline Lepidosperma laterale & Cyperaceae & $\mathrm{n}$ & $x$ & & & & $\mathrm{R}$ \\
\hline Lepidosperma tortuosum & Cyperaceae & $\mathrm{n}$ & $x$ & & & & \\
\hline Leptospermum scoparium & Myrtaceae & $\mathrm{n}$ & $x$ & $x$ & 4 & 4 & $\mathrm{R} / \mathrm{S}$ \\
\hline Leucopogon collinus & Epacridaceae & $\mathrm{n}$ & $x$ & & & & S \\
\hline Leucopogon parviflorus & Epacridaceae & $\mathrm{n}$ & & $x$ & & & $\mathrm{R}$ \\
\hline Lindsaea linearis & Lindsaeaceae & $\mathrm{n}$ & $x$ & $x$ & & & $\mathrm{R}$ \\
\hline Lobelia anceps & Campanulaceae & $\mathrm{n}$ & & & 1 & 3 & \\
\hline Lomatia tinctoria & Proteaceae & $\mathrm{n}$ & $x$ & & & & \\
\hline Lycopodiella lateralis & Lycopodiaceae & $\mathrm{n}$ & $x$ & & & & $\mathrm{R}$ \\
\hline Lycopodium deuterodensum & Lycopodiaceae & $\mathrm{n}$ & $x$ & $x$ & & & $\mathrm{R}$ \\
\hline Melaleuca squamea & Myrtaceae & $\mathrm{n}$ & $x$ & $x$ & & & S \\
\hline Melaleuca squarrosa & Myrtaceae & $\mathrm{n}$ & $x$ & $x$ & & & Rs \\
\hline Mitrasacme pilosa & Loganiaceae & $\mathrm{n}$ & $x$ & & 6 & 3 & \\
\hline Opercularia varia & Rubiaceae & $\mathrm{n}$ & & & 4 & 3 & $\mathrm{Sr}$ \\
\hline Ozothamnus ferrugineus & Asteraceae & $\mathrm{n}$ & & & 3 & 6 & S \\
\hline Persoonia juniperina & Proteaceae & $\mathrm{n}$ & $x$ & & & & Rs \\
\hline Pimelea linifolia & Thymelaeaceae & $\mathrm{n}$ & $x$ & & 2 & 0 & $\mathrm{~S} / \mathrm{R}$ \\
\hline Роа аппиа & Poaceae & $\mathrm{i}$ & & & 0 & 1 & S \\
\hline
\end{tabular}


Table 2 continued

\begin{tabular}{|c|c|c|c|c|c|c|c|}
\hline Species & Family & Status & 1976 & 2013 & $\mathrm{SB}(\mathrm{h})$ & $\mathrm{SB}(\mathrm{n})$ & $\begin{array}{l}\text { Fire } \\
\text { tolerance }\end{array}$ \\
\hline Pteridium esculentum & Dennstaedtiaceae & $\mathrm{n}$ & $x$ & & & & $\mathrm{R}$ \\
\hline Pultenaea gunnii & Fabaceae & $\mathrm{n}$ & $x$ & & & & \\
\hline Pultenaea juniperina & Fabaceae & $\mathrm{n}$ & $x$ & & & & \\
\hline Sagina procumbens & Caryophyllaceae & $\mathrm{i}$ & & & 0 & 4 & \\
\hline Schizaea fistulosa & Schizaeaceae & $\mathrm{n}$ & $\times$ & & & & \\
\hline Schoenus lepidosperma & Cyperaceae & $\mathrm{n}$ & $\times$ & $\times$ & 1 & 1 & $\mathrm{R}$ \\
\hline Selaginella uliginosa & Selaginellaceae & $\mathrm{n}$ & $x$ & $x$ & & & $\mathrm{R}$ \\
\hline Senecio biserratus & Asteraceae & $\mathrm{n}$ & & & 0 & 1 & $\mathrm{~S}$ \\
\hline Sprengelia incarnata & Epacridaceae & $\mathrm{n}$ & $x$ & & & & $\mathrm{Sr}$ \\
\hline Stylidium graminifolium & Stylidiaceae & $\mathrm{n}$ & $\times$ & & & & Rs \\
\hline Tetraria capillaris & Cyperaceae & $\mathrm{n}$ & $x$ & & & & $\mathrm{R}$ \\
\hline Tetrarrhena distichophylla & Poaceae & $\mathrm{n}$ & $x$ & $x$ & & & \\
\hline Trifolium repens & Fabaceae & $\mathrm{i}$ & & & 2 & 0 & \\
\hline Vellereophyton dealbatum & Asteraceae & $\mathrm{i}$ & & & 0 & 3 & $\mathrm{~S}$ \\
\hline Xanthosia dissecta & Apiaceae & $\mathrm{n}$ & & $x$ & 4 & 3 & $\mathrm{R}$ \\
\hline Xanthosia tasmanica & Apiaceae & $\mathrm{n}$ & $x$ & & 1 & 0 & \\
\hline Xyris operculata & Xyridaceae & $\mathrm{n}$ & $x$ & & & & $\mathrm{R}$ \\
\hline Asteraceae sp. & Asteraceae & $?$ & & & 0 & 2 & \\
\hline Epacridaceae sp. & Epacridaceae & $\mathrm{n}$ & & & 3 & 0 & \\
\hline Myrtaceae sp. & Myrtaceae & $\mathrm{n}$ & & & 3 & 0 & \\
\hline Herb 1 & - & $?$ & & & 3 & 0 & \\
\hline Herb 2 & - & $?$ & & & 1 & 1 & \\
\hline
\end{tabular}

\section{References}

Auld TD, O'Connell MA (2006) Predicting patterns of post-fire germination in 35 eastern Australian Fabaceae. Aust J Ecol 16(1):53-70

Baker ML, de Salas MF (2013) A census of the vascular plants of Tasmania. Tasmanian Herbarium, Tasmanian Museum and Art Gallery, Hobart

Bell DT (1999) Turner Review No. 1. The process of germination in Australian species. Aust J Bot 47(4):475-517

Bell DT, Hopkins AJM, Pate JS (1984) Fire in the kwongan. In: Pate JS, Beard JS (eds) kwongan. Plant life of the sandplain. University of Western Australia Press, Perth, pp 178-204

Bezemer N, Kirkpatrick JB, Wood JA (2013) The effect of recent fire history on the abundance and viability of large seeds in the soil of sclerophyll forest in Tasmania, Australia. Pap Proc R Soc Tasmania $147: 41-50$

Bond WJ, Keeley JE (2005) Fire as a global 'herbivore': the ecology and evolution of flammable ecosystems. Trends Ecol Evol 20(7):387-394

Bradstock RA, Myerscough PJ (1981) Fire effects on seed release and the emergence and establishment of seedlings in Banksia ericifolia. Lf. Aust J Bot 29(5):521-531

Bradstock RA, Bedward M, Scott J, Keith DA (1996) Simulation of the effect of spatial and temporal variation in fire regimes on the population viability of a Banksia species. Conserv Biol 10(3):776-784

Bradstock RA, Tozer MG, Keith DA (1997) Effects of high frequency fire on floristic composition and abundance in a fire-prone heathland near Sydney. Aust J Bot 45(4):641-655

Brown NAC (1993) Promotion of germination of fynbos seeds by plant-derived smoke. New Phytol 123(3):575-583 
Brown S, Clarke M, Clarke R (2009) Fire is a key element in the landscape-scale habitat requirements and global population status of a threatened bird: the Mallee Emu-wren (Stipiturus mallee). Biol Conserv 142(2):432-445

Chladil MA, Kirkpatrick JB (1989) A transect study of the sand dune vegetation at Bakers Beach, Tasmania. Pap Proc R Soc Tasmania 123:247-256

Core Team R (2013) R: a language and environment for statistical computing. R Foundation for Statistical Computing, Vienna

Crosti R, Ladd PG, Dixon KW, Piotto B (2006) Post-fire germination: the effect of smoke on seeds of selected species from the central Mediterranean basin. For Ecol Manag 221(1):306-312

Davies RJ-P, Whalen MA, Mackay DA, Taylor D, Pisanu P (2013) Does soil seed bank diversity limit postfire regeneration in small, fragmented, long-unburnt remnants of fire adapted vegetation? Biol Conserv 158:287-295

di Folco M-B, Kirkpatrick JB (2013) Organic soils provide evidence of spatial variation in human-induced vegetation change following European occupation of Tasmania. J Biogeogr 40(1):197-205

Dixon KW, Roche S, Pate JS (1995) The promotive effect of smoke derived from burnt native vegetation on seed germination of Western Australian plants. Oecologia 101(2):185-192

Enright NJ, Keith DA, Clarke MF, Miller BP (2012) Fire regimes in Australian sclerophyllous shrubby ecosystems: heathlands, heathy woodlands and mallee woodlands. In: Bradstock RA, Gill AM, Williams RJ (eds) Flammable Australia: Fire Regimes and Biodiversity in a Changing World. CSIRO Publishing, Melbourne, pp 215-235

Gill AM (1981) Adaptive responses of Australian vascular plant species to fires. In: Gill AM, Groves RH, Noble IR (eds) Fire and the Australian biota. Australian Academy of Science, Canberra, pp 243-272

Gill AM (1999) Biodiversity and bushfires: an Australia-wide perspective on plant-species changes after a fire event. In: Gill AM, Woinarski J, York A (eds) Australia's biodiversity-responses to fire: plants, birds and invertebrates. Environment Australia Biodiversity Technical Paper 1, pp 9-53

Gill AM, Stephens SL (2009) Scientific and social challenges for the management of fire-prone wildlandurban interfaces. Environ Res Lett 4(3):034014

Gilmour CA, Crowden RK, Koutoulis A (2000) Heat shock, smoke and darkness: partner cues in promoting seed germination in Epacris tasmanica (Epacridaceae). Aust J Bot 48(5):603-609

Gimingham CH (1972) Ecology of heathlands. Chapman Hall, London

Gimingham C (1994) Lowland heaths of West Europe: management for conservation. Phytocoenologia 24:615-626

Gosper CR, Yates CJ, Prober SM, Parsons BC (2012) Contrasting changes in vegetation structure and diversity with time since fire in two Australian Mediterranean-climate plant communities. Aust Ecol 37(2):164-174

Harris S, Kitchener A (2005) From forest to fjaeldmark: descriptions of Tasmania's vegetation. Department of Primary Industry, Water and Environment, Hobart

Hayes M, Kirkpatrick JB (2012) Influence of Ammophila arenaria on half a century of vegetation change in eastern Tasmanian sand dune systems. Aust J Bot 60(5):450-460

Hazard J, Parsons RF (1977) Size-class analysis of coastal scrub and woodland, Western Port, southern Australia. Aust J Ecol 2(2):187-197

Humphreys SR, Craig G (1981) Effects of fire on soil chemical, structural and hydrological properties. In: Gill AM, Groves RH, Noble IR (eds) Fire and the Australian biota. Australian Academy of Science, Canberra, pp 177-200

Kaland PE (1986) The origin and management of Norwegian coastal heaths as reflected by pollen analysis. In: Behre KE (ed) Anthropogenic indicators in pollen analysis. Balkema, Rotterdam/Boston, pp 19-36

Kattge J, Diaz S, Lavorel S, Prentice IC, Leadley P, Bönisch G, Garnier E, Westoby M, Reich PB, Wright IJ (2011) TRY-a global database of plant traits. Glob Change Biol 17(9):2905-2935

Keeley JE (1986) Resilience of Mediterranean shrub communities to fires. In: Dell B, Hopkins AJM, Lamont BB (eds) Resilience in Mediterranean-type ecosystems, vol 16. Springer, Dordrecht, pp 95-112

Keeley JE, Bond WJ (1997) Convergent seed germination in South African fynbos and Californian chaparral. Plant Ecol 133(2):153-167

Keeley JE, Fotheringham CJ (1997) Trace gas emissions and smoke-induced seed germination. Science 276:1248-1250

Keeley JE, Bond WJ, Bradstock RA (2011) Fire in Mediterranean ecosystems: ecology, evolution and management. Cambridge University Press, Cambridge

Keith DA (1997) Combined effects of heat shock, smoke and darkness on germination of Epacris stuartii Stapf., an endangered fire-prone Australian shrub. Oecologia 112(3):340-344 
Keith DA, McCaw WL, Whelan RJ (2002) Fire regimes in Australian heathlands and their effects on plants and animals. In: Bradstock RA, Williams JE, Gill AM (eds) Flammable Australia: the fire regimes and biodiversity of a continent. Cambridge University Press, Cambridge, pp 199-237

Kenny BJ (2000) Influence of multiple fire-related germination cues on three Sydney Grevillea (Proteaceae) species. Austral Ecol 25(6):664-669

Kirkpatrick JB (1977) The disappearing heath. Tasmanian Conservation Trust, Hobart

Kirkpatrick JB (1995) The vegetation of Dover and Erith Islands, Kent Group, Bass Strait. Pap Proc R Soc Tasmania 129:25-33

Kirkpatrick JB, Harris S (1999) The disappearing heath revisited. Tasmanian Environment Centre Inc, Hobart

Lange JH, Boucher C (1990) Autecological studies on Audouinia capitata (Bruniaceae). I. Plant-derived smoke as a seed germination cue. South Afr J Bot 56(6):700-703

Leck MA, Parker T, Simpson RL (1989) Ecology of soil seed banks. Academic Press Inc., San Diego

Loofs-Samorzewski M (2003) The impacts of edge effects and other disturbances on Tasmanian coastal heathlands. University of Tasmania, Hobart

Molnar CD, Fletcher D, Parsons RF (1989) Relationships between heath and Leptospermum laevigatum scrub at Sandringham, Victoria. Proc R Soc Victoria 101:77-87

Moreira B, Tormo J, Estrelles E, Pausas JG (2010) Disentangling the role of heat and smoke as germination cues in Mediterranean Basin flora. Ann Bot 105(4):627-635

Pausas JG, Bradstock RA, Keith DA, Keeley JE (2004) Plant functional traits in relation to fire in crown-fire ecosystems. Ecology 85(4):1085-1100

Pyrke AF, Marsden-Smedley JB (2005) Fire-attributes categories, fire sensitivity, and flammability of Tasmanian vegetation communities. Tasforests 16:35-46

Richardson DM, Van Wilgen BW, Higgins SI, Trinder-Smith TH, Cowling RM, McKell DH (1996) Current and future threats to plant biodiversity on the Cape Peninsula, South Africa. Biodivers Conserv 5(5):607-647

Russell RP, Parsons RF (1978) Effects of time since fire on heath floristics at Wilson's Promontory, southern Australia. Aust J Bot 26(1):53-61

Schwilk DW, Keeley JE, Bond WJ (1997) The intermediate disturbance hypothesis does not explain fire and diversity pattern in fynbos. Plant Ecol 132(1):77-84

Thomas I, Kirkpatrick JB (1996) The roles of coastlines, people and fire in the development of heathlands in northeast Tasmania. J Biogeogr 23(5):717-728

Tucker CM, Cadotte MW (2013) Fire variability, as well as frequency, can explain coexistence between seeder and resprouter life histories. J Appl Ecol 50(3):594-602

Van Staden J, Brown NAC, Jäger AK, Johnson TA (2000) Smoke as a germination cue. Plant Species Biol 15(2):167-178

Vivian LM, Doherty MD, Cary GJ (2010) Classifying the fire-response traits of plants: how reliable are species-level classifications? Aust Ecol 35(3):264-273

Wicklow DT (1977) Germination response in Emmenanthe penduliflora (Hydrophyllaceae). Ecology 58(1):201-205

Wills TJ, Read J (2002) Effects of heat and smoke on germination of soil-stored seed in a south-eastern Australian sand heathland. Aust J Bot 50(2):197-206

Wills TJ, Read J (2007) Soil seed bank dynamics in post-fire heathland succession in south-eastern Australia. Plant Ecol 190(1):1-12 